\title{
Hepatitis B virus genotypes and mutations in the basal core promoter and pre-core/core in chronically infected patients in southern Brazil: a cross-sectional study of HBV genotypes and mutations in chronic carriers
}

\author{
Flávia Miryan Martins Almeida de Mello ${ }^{[1]}$, Aline Satie Oba Kuniyoshi ${ }^{[2]}$, \\ André Fanhani Lopes ${ }^{[1]}$, Michele Soares Gomes-Gouvêa ${ }^{[3]}$ \\ and Dennis Armando Bertolini ${ }^{[1]}$
}

\begin{abstract}
[1]. Laboratório de Virologia Clínica, Departamento de Análises Clínicas e Biomedicina, Universidade Estadual de Maringá, Maringá, PR. [2]. Consórcio Intermunicipal de Saúde do Setentrião Paranaense, Maringá, PR. [3]. Laboratório de Gastroenterologia Tropical do Instituto de Medicina Tropical, Faculdade de Medicina, Universidade de São Paulo, São Paulo, SP.
\end{abstract}

\begin{abstract}
Introduction: In Brazil, little data exist regarding the distribution of genotypes in relation to basal core promoter (BCP) and precore/core mutations among chronic hepatitis B virus (HBV) carriers from different regions of the country. The aim of this study was to identify HBV genotypes and the frequency of mutations at the BCP and precore/core region among the prevalent genotypes in chronic carriers from southern Brazil. Methods: Nested-polymerase chain reaction (nested-PCR) products amplified from the S-polymerase gene, BCP and precore/core region from 54 samples were sequenced and analyzed. Results: Phylogenetic analysis of the S-polymerase gene sequences showed that $66.7 \%(36 / 54)$ of the patients were infected with genotype D (D1, D2, D3), $25.9 \%$ (14/54) with genotype A (A1, A2), 5.6\% (3/54) with subgenotype C2, and 2\% (1/54) with genotype E. A comparison of virological characteristics showed significant differences between genotypes A, C and D. The comparison between $\mathrm{HBe} A g$ status and the G1896A stop codon mutation in patients with genotype D revealed a relationship between HBV G1896A precore mutants and genotype D and hepatitis B $e$ antigen (HBeAg) seroconversion. Genotype D had a higher prevalence of the G1896A mutation and the presence of a thymine at position 1858. Genotype A was associated with a higher prevalence of the G1862T mutation and the presence of a cytosine at position 1858. Conclusions: HBV genotype D (D3) is predominant in HBV chronic carriers from southern Brazil. The presence of mutations in the BCP and precore/core region was correlated with the HBV genotype and $\mathrm{HBeAg}$ negative status.
\end{abstract}

Keywords: HBV. Genotypes. Subgenotypes. Basal core promoter mutations. Precore/core mutations.

\section{INTRODUCTION}

Infection with hepatitis B virus (HBV) is an important worldwide cause of morbidity and mortality, especially in developing countries ${ }^{1-3}$. In Brazil, approximately $15 \%$ of the population has been in contact with HBV, and 1 to $3 \%$ of the population is chronically infected ${ }^{4}$. Persistent infection with $\mathrm{HBV}$ is intimately associated with the development of cirrhosis and hepatocellular carcinoma (HCC), and $\mathrm{HBV}$ is the primary cause of acute and chronic liver disease, causing 1 million deaths per year ${ }^{5}$.

\footnotetext{
Address to: Dr. Dennis Armando Bertolini. Laboratório de Virologia Clínica/ Depto. de Análises Clínicas e Biomedicina/UEM. Av. Colombo 5790, 87020-900 Maringá, PR, Brasil.

Phone: 5544 3011-5394; Fax: 5544 3011-4860

e-mail: dabertolini@uem.br

Received 11 August 2014

Accepted 11 November 2014
}

Hepatitis B virus is currently classified into nine genotypes (A-I) that are defined based on intergroup differences of more than $8 \%$ in the complete genome sequence and of more than $4 \%$ in the $\mathrm{S}$ gene with genotypes $\mathrm{F}$ and $\mathrm{H}$ being the most divergent $t^{6-8}$. Epidemiological studies have shown that each genotype is characterized by a distinct geographic and ethnic distribution ${ }^{9}$. In brief, genotype A is prevalent in northwestern Europe, North America and Africa ${ }^{6,10,11}$. Genotypes B and C are commonly found in Asia ${ }^{7,9-11}$, whereas genotype D shows a worldwide distribution but predominates in the Mediterranean region, including the Middle East and central Asia ${ }^{10-12}$. Genotype $\mathrm{E}$ is found in the Western region of Africa ${ }^{10,13,14}$, genotype $\mathrm{F}$ is present in the aboriginal population of South America, and genotype $\mathrm{H}$ is confined to Central America. Genotype $\mathrm{G}$ was initially isolated from HBV carriers in France and Georgia (United States) ${ }^{8}$ and was later detected in the United Kingdom ${ }^{11}$, Italy ${ }^{11}$ and Germany ${ }^{15}$. Recently, HBV genotype I was described in northwestern China, Vietnam and Laos ${ }^{16,17}$. Finally, a recently identified tenth genotype provisionally assigned as genotype $J$ was proposed for a HBV isolate from a Japanese patient 
with $\mathrm{HCC}^{18}$. Previous studies have shown that $\mathrm{A}, \mathrm{D}$ and $\mathrm{F}$ are the primary genotypes circulating in Brazil ${ }^{19,20}$.Furthermore, phylogenetic studies have demonstrated that the A, B, C, D and F $\mathrm{HBV}$ genotypes can be subdivided into subgenotypes. Evidence indicates that genotypes and associated subgenotypes differ in virological characteristics that may be related to differences in the clinical evolution of liver disease and response to treatment ${ }^{21}$.

The occurrence of various mutations in the HBV genome during the course of persistent viral infection has been reported, and increasing evidence of an association between molecular changes (mainly in the precore gene and the basal core promoter region) and the development of HCC in patients infected with HBV has been described ${ }^{22}$.

Studies have demonstrated a correlation between HBV genotypes and the development of mutations in the precore gene and in the basal core promoter (BCP) region ${ }^{1,10,23}$. The wellknown naturally occurring HBV variants include the precore stop codon mutation (G1896A), which abolishes hepatitis B $e$ antigen $(\mathrm{HBe} A g)$ production and serves to enhance the stability of the secondary structure of the pre-genome encapsidation signal, favoring the maintenance of viral replication ${ }^{23-25}$. The other common HBV variants include double mutations in the $\mathrm{BCP}$ region $(\mathrm{A} 1762 \mathrm{~T} / \mathrm{G} 1764 \mathrm{~A})$, which occur in a regulatory region ${ }^{25-27}$. Apart from these variants, other mutations such as $\mathrm{T} 1753 \mathrm{~V}$ in the $\mathrm{BCP}$ region, G1899A in the precore region and $\mathrm{G} 1862 \mathrm{~T}$ in the precore region have been identified and are associated with $\mathrm{HCC}$ development, $\mathrm{HBeAg}$ production and the reverse transcription process, respectively ${ }^{1,28-35}$.

The identification of patients presenting with risk factors for the development of advanced liver disease such as HCC among chronic hepatitis B carriers is important. Many clinical and virological factors potentially associated with an increased risk of $\mathrm{HCC}$ have been identified ${ }^{36}$ such as male gender and advanced age $\mathrm{e}^{37}$, virological factors such as HBeAg positivity, elevated serum levels of viral deoxyribonucleic acid (DNA), genotype and mutations in the $\mathrm{BCP}$ and precore/core gene ${ }^{38}$, and clinical liver disease factors such as enzyme levels (alanine aminotransferase) and the presence of cirrhosis ${ }^{36,39}$.

In Brazil, a geographically large country with a history of intense heterogeneous migration, little data exist regarding the distribution of genotypes in relation to $\mathrm{BCP}$ and precore/ core mutations available from different regions of the country. Thus, the objective of the present study was to investigate the molecular characteristics of $\mathrm{HBV}$ in chronic carriers from a region located in southern Brazil to identify HBV genotypes and the frequency of mutation at the $\mathrm{BCP}$ and the precore/core region among the prevalent genotypes.

\section{METHODS}

\section{Patients}

This study included samples collected between 2007 and 2008 from 71 patients chronically infected with HBV. These patients were from the northwestern region of the State of Paraná located in southern Brazil.
The patients were under medical assistance at the Hepatitis Outpatient Clinic of the Consórcio Intermunicipal de Saúde do Setentrião Paranaense (CISAMUSEP). The serum was separated from 10-ml blood samples, and the samples were stored in two aliquots at $-20^{\circ} \mathrm{C}$ and thawed immediately prior to the tests.

The data regarding the stage of infection, gender, age, $\mathrm{HBeAg}$ status, and blood levels of alanine aminotransferase (ALT) and aspartate aminotransferase (AST) classified as normal or elevated (when higher than two times the upper limit of normal) were obtained from the patient records.

\section{Detection of HBV DNA by PCR}

Hepatitis B virus deoxyribonucleic acid was extracted using phenol-chloroform ${ }^{40}$ followed by ethanol precipitation. HBV DNA was amplified by nested polymerase chain reaction (nested-PCR) using previously described primers. For the $\mathrm{BCP}$ and precore/core regions, the EP1.1/2032 (first round) and EP2.1/2017R (second round) primers yielded a 501-bp fragment ${ }^{34,41}$. The PCR was conducted in a thermocycler (Techne TC-512, Techne Inc, NJ, USA) under the following conditions: initial denaturation at $94^{\circ} \mathrm{C}$ for $1 \mathrm{~min}$; followed by 30 cycles at $94^{\circ} \mathrm{C}$ for $1 \mathrm{~min}, 45.5^{\circ} \mathrm{C}$ for $1 \mathrm{~min}$ and $72^{\circ} \mathrm{C}$ for $1 \mathrm{~min}$; and a final extension step at $72^{\circ} \mathrm{C}$ for $5 \mathrm{~min}$.

The S-polymerase (S-Pol) gene was amplified using the FHBS1/RADE1 (first round) and FHBS2/RADE2 (second round) primers, yielding a 734-bp fragment ${ }^{20,42}$. The amplification conditions for the S-Pol gene only differed in terms of the annealing temperature, which was $56^{\circ} \mathrm{C}$ in the first step and $50^{\circ} \mathrm{C}$ in the second step: initial denaturation at $94^{\circ} \mathrm{C}$ for $1 \mathrm{~min}$; followed by 34 cycles at $94^{\circ} \mathrm{C}$ for $30 \mathrm{~s}, 56 / 50^{\circ} \mathrm{C}$ for $30 \mathrm{~s}$ and $72^{\circ} \mathrm{C}$ for $30 \mathrm{~s}$; with a final extension step at $72^{\circ} \mathrm{C}$ for $7 \mathrm{~min}$. The PCR products were separated by electrophoresis on a $1 \%$ agarose gel, stained with ethidium bromide and observed under ultraviolet light.

\section{Sequencing}

After purification, the PCR products were sequenced according to a previously described method ${ }^{43}$ using the EP2.1 and 2017R primers for the $\mathrm{BCP}$ and the precore/core region and FHBS2, RHBS2, 5' ${ }^{\prime} \mathrm{AM}^{44}$ and RADE2 primers for S-Pol with fluorescent-labeled dideoxynucleotides (ddNTPs) using the ABI Prism ${ }^{\circledR}$ BigDyeTM Terminator Cycle Sequencing Ready Reaction Kit (Applied Biosystems, Foster City, CA). After precipitation and purification of the reaction product, the samples were denatured and sequenced in an automatic ABI 3100 sequencer (Applied Biosystems).

\section{Sequence analysis}

The sequences obtained were first analyzed using the PhredPhrap program (http://asparagin.cenargen.embrapa.br/phph/) to determine the data quality and construction of the consensus sequence using nucleotide bases with a score $>20$. Genotyping and analysis of the $\mathrm{BCP}$ and precore mutants were performed by comparison of the sequences obtained with the sequences of different HBV genotypes previously published in GenBank. The accession numbers of the sequences used are shown in Figure 1. The BioEdit Sequence Alignment Editor, version 7.0.9.045 and 


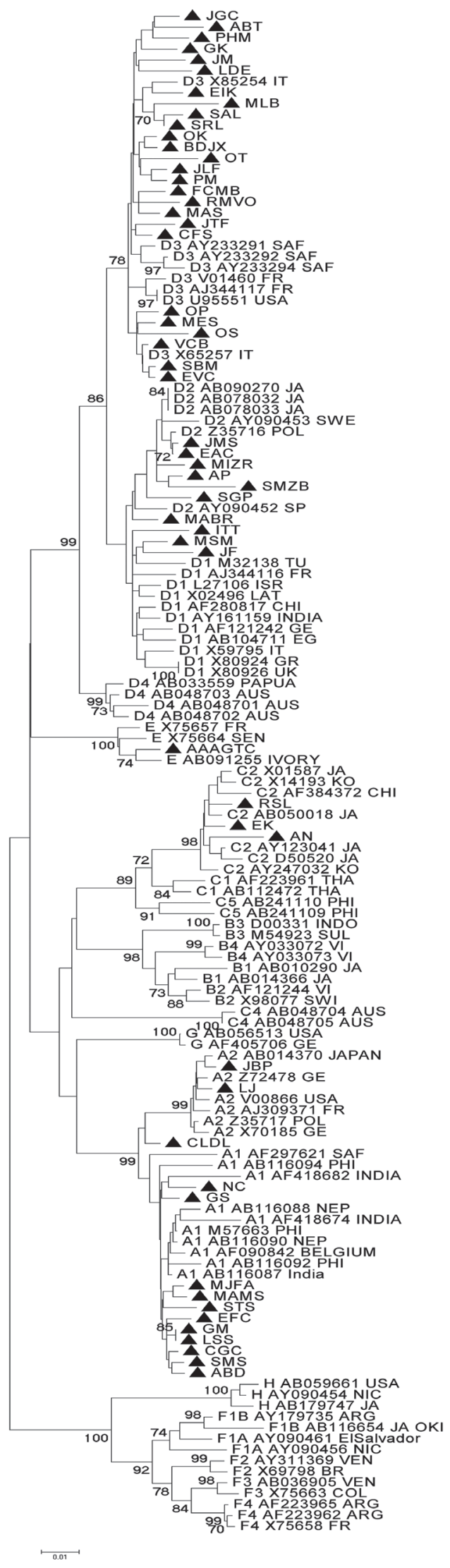

FIGURE 1 - Phylogenetic tree generated by neighbor-joining analysis of the HBV sequences obtained $(\Delta)$ from patients $(n=54)$ in the Northwestern region of Paraná in the South of Brazil, between 2007 and 2008. HBV: hepatitis B virus.
Clustal X, version 2.0.946 programs were used for sequence analysis and editing. Phylogenetic analysis was performed with the Mega 4 (Molecular Evolutionary Genetics Analysis) package $^{47}$. The aligned dataset of S-Pol gene sequences were analyzed by the neighbor-joining method. Genetic distances were calculated using Kimura's two-parameter model. Bootstrap analysis with 1,000 replicates was performed to test the reliability of the tree with values $\geq 70$ indicated on the branches.

\section{Statistical analysis}

All data were analyzed using the Statistica $8.0^{48}$ and SAS version 9.1.3 $3^{49}$ packages. Fisher's exact test was used to compare categorical variables. Continuous data were compared by analysis of variance (ANOVA) and the Student t-test. Ap value $<0.05$ was considered statistically significant.

\section{GenBank accession numbers}

The sequences were deposited in GenBank under the accession numbers FJ865506 to FJ865559 (S-Pol gene) and FJ969215 to FJ969268 (BCP and precore/core gene).

\section{Ethical considerations}

The study was approved by the Ethics Committee on Human Research of Universidade Estadual de Maringá, and each patient signed a free informed consent form (CAAE Number 0181.0.093.000-06; protocol 319/2006).

\section{RESULTS}

\section{HBV Genotyping}

Hepatitis B virus deoxyribonucleic acid was detected in plasma samples from $56(79 \%)$ of the 71 patients included in this study. However, the BCP, precore/core and S-Pol gene regions could only be sequenced in $54(76 \%)$ samples. These 54 patients had a mean age of $42 \pm 12.9$ years, and $30(55.6 \%)$ were males and 24 (44.4\%) were females.

Phylogenetic analysis of the S-Pol region revealed welldefined clusters and statistical significance for all genotypes with a bootstrap result higher than $89 \%$ for the main branches (Figure 1). Thirty-six (66.7\%) of the 54 patients were infected with genotype D, 14 (25.9\%) with genotype A, three (5.6\%) with genotype $\mathrm{C}$, and one (1.8\%) with genotype $\mathrm{E}$. The subgenotypes identified in the present study are displayed in Figure 1, and the frequency of HBV genotypes and subgenotypes in the 54 patients studied is shown in Figure 2.

No significant differences in clinical and demographic characteristics [age, gender, $\mathrm{HBeAg}$ positivity rate and altered serum alanine aminotransferase (ALT) and aspartate aminotransferase (AST) levels] were observed in patients infected with the HBV genotypes A, C and D (Table 1). Data from the only patient infected with genotype $\mathrm{E}$ are not listed in Table 2, but he was male, 29 years old, had normal levels of ALT and AST, was HBeAg negative, and the virus had the G1896A stop codon mutation and a $\mathrm{T}$ at position 1858 . 


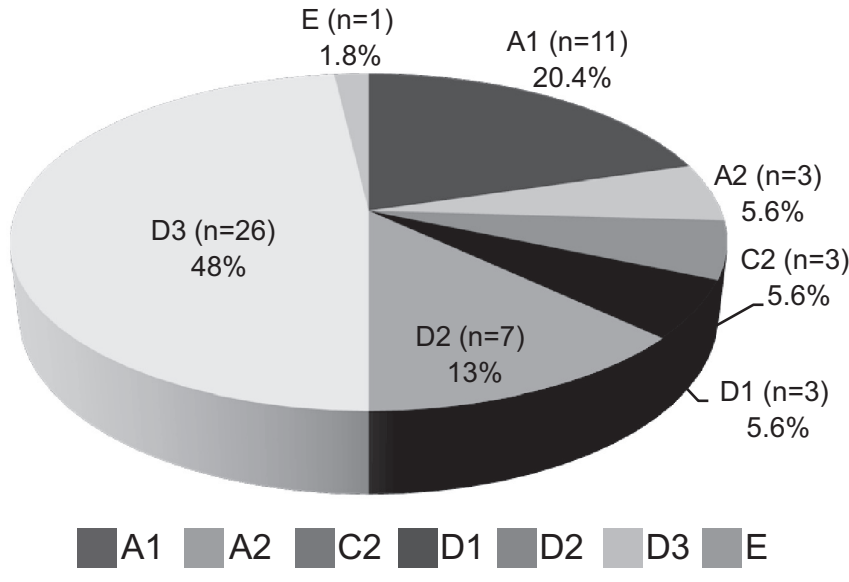

FIGURE 2 - Distribution of HBV genotypes and subgenotypes isolated from patients $(n=54)$ in the Northwestern region of the State of Paraná in Southern Brazil between 2007 and 2008. HBV: hepatitis B virus.

\section{Precore/core mutations and genotype}

Analysis of the $\mathrm{BCP}$ and precore/core sequences in the 54 samples showed that the G1896A precore mutation was the most frequent $(30 / 54,55.6 \%)$ followed by the BCP double mutation A1762T/G1764A (22/54, 40.7\%), the BCP T1753V mutation $(18 / 54,33.3 \%)$ and the G1899A (14/54, 26\%) and $\mathrm{G} 1862 \mathrm{~T}(11 / 54,20.4 \%)$ precore region mutations. All 30 samples identified as G1896A mutants had a thymine (T) at position $1858,83.3 \%(15 / 18)$ of the $\mathrm{T} 1753 \mathrm{~V}$ mutants had the BCP double mutation, and 9 samples $(16.6 \%$ - 9/54) carried all these mutations simultaneously.

Comparison of the virological characteristics showed significant differences between genotypes $\mathrm{A}, \mathrm{C}$ and $\mathrm{D}$, especially in terms of the G1896A and G1862T mutations and the presence of a thymine at position $1858(\mathrm{p}<0.001)$. Comparison of genotypes $\mathrm{A}, \mathrm{C}$ and D showed a lower frequency of the A1762T/G1764A mutation in genotype D samples, whereas the G1896A mutation was the most frequent in this genotype $(\mathrm{p}<0.001)$ (Table 1).

Among the genotypes identified, genotype A presented the highest frequency of the G1862T mutation, which differed significantly $(p=0.027)$ between the subgenotypes A1 and A2 because this mutation was present only in samples from patients infected with A1. Thus, HBV genotype A was characterized by a higher frequency of the A1762T/G1764A and G1862T mutations and a lower frequency of the G1899A mutation compared with the other genotypes. A cytosine was found at position 1858 in $78.6 \%$ of the infected samples with genotype A. However, a thymine at this same position was found in two samples infected

TABLE 1 - Clinical and virological differences between HBV genotypes A, C and D isolated from chronically infected patients from the Northwestern region of the State of Paraná in Southern Brazil between 2007 and 2008.

\begin{tabular}{|c|c|c|c|c|}
\hline Characteristic & $\begin{array}{c}A \\
(n=14)\end{array}$ & $\begin{array}{c}C \\
(n=3)\end{array}$ & $\begin{array}{c}D \\
(n=36)\end{array}$ & $\mathrm{p}$ \\
\hline \multicolumn{5}{|l|}{ Age (years) } \\
\hline mean $\pm \mathrm{SD}$ & $42.7 \pm 10.6$ & $48 \pm 8.5$ & $42 \pm 12.95$ & $0.712 \#$ \\
\hline range & $(31-70)$ & $(39-56)$ & $(20-67)$ & \\
\hline Gender (male/female) & $9 / 5$ & $2 / 1$ & $18 / 18$ & $0.646 \S$ \\
\hline HBeAg-positive patients, $\mathrm{n}(\%)$ & $3(21.4 \%)$ & $1(33.3 \%)$ & $4(11.1 \%)$ & $0.304 \S$ \\
\hline \multicolumn{5}{|l|}{ Indicators of liver function } \\
\hline elevated ALT, n (\%)* & $2(14.0 \%)$ & $1(33.3 \%)$ & $7(19.4 \%)$ & $0.702 \S$ \\
\hline A1762T G1764A & $9(64.3 \%)$ & $2(66.7 \%)$ & $11(30.5 \%)$ & $0.050 \S$ \\
\hline G1896A & $0(0.0 \%)$ & $1(33.3 \%)$ & $28(77.7 \%)$ & $<0.001 \S$ \\
\hline $\mathrm{C} 1858 \mathrm{~T}$ & $3(21.4 \%)$ & $3(100.0 \%)$ & $36(100.0 \%)$ & $<0.001 \S$ \\
\hline G1899A & $1(7.1 \%)$ & $1(33.3 \%)$ & $12(33.3 \%)$ & $0.122 \S$ \\
\hline G1862T & $9(64.0 \%)$ & $0(0.0 \%)$ & $2(5.5 \%)$ & $<0.001 \S$ \\
\hline
\end{tabular}

*When higher than 2 times the upper limit of normal; \#ANOVA; §Fisher's exact test; Note: The data from the only patient infected with genotype E are not present in the table. HBV: hepatitis B virus; SD: standard deviation; HBeAg: hepatitis B $e$ antigen; ALT: alanine aminotransferase; AST: aspartate aminotransferase; ANOVA: analysis of variance. 
with subgenotype A1, which did not have any of the mutations described in this work. However, one sample classified as $\mathrm{A} 2 \mathrm{had}$ a $\mathrm{T}$ at position 1858 and carried the A1762T/G1764A and G1899A mutations. None of the patients infected with the HBV genotype A carried the G1896A mutation. Genotype C was characterized by a higher frequency of the A1762T/G1764A mutation and an intermediate frequency of the G1896A and G1899A mutations, whereas none of the patients carried the G1862T mutation. Genotype D had a higher frequency of the G1896A mutation, an intermediate frequency of the A1762T/ G1764A and G1899A mutations, and a low frequency of the G1862T mutation. The presence of a $\mathrm{T}$ at position 1858 was specific for genotypes $\mathrm{C}$ and $\mathrm{D}$, and an intermediate frequency of the T1753V mutation was observed in all genotypes (Table 1).

\section{Precore/core mutations and HBeAg status}

Eight (14.8\%) of the 54 patients were HBeAg positive, and $46(85.2 \%)$ patients were $\mathrm{HBe} A g$ negative. When comparing this qualitative variable with the mutations identified in the $\mathrm{BCP}$ and precore/core gene regions, significant differences were observed compared with the G1896A stop codon mutation ( $p<0.001)$. All 30 samples identified as G1896A mutants were HBeAg negative and corresponded to $65.2 \%(30 / 46)$ of HBeAg-negative patients. Of the other $16 \mathrm{HBeAg}$ negative samples, three (18.8\%) had the double mutation (A1762T/G1764A) plus the T1753V and the G1862T mutations, three (18.8\%) had the G1862T mutation and the double mutation, three $(18.8 \%)$ others did not have any of the mutations analyzed in this study, two (12.5\%) had only the double mutation, one (6.2\%) sample had the T1753V mutation plus theA1762T/G1764A and G1899A mutations, one (6.2\%) had the double and the T1753V mutations, one $(6.2 \%)$ had the double and the G1899A mutation, and one (6.2\%) had only the G1899A mutation. One (6.2\%) sample had the G1862T mutation but was found to contain a mutation at position 1814 substituting $\mathrm{A}$ for $\mathrm{C}$, which altered the start codon of the precore gene leading to the loss of $\mathrm{HBe} A g$ translation. None of the $\mathrm{HBeAg}$-positive patients carried the G1896A stop codon mutation in the precore gene.

In genotype $\mathrm{D}, 32 / 36(89 \%)$ samples were classified as $\mathrm{HBeAg}$ negative and 28/36 (77.7\%) as G1896A mutants. Significant differences were observed when comparing these two variables (HBeAg x G1896A) among the genotype D sequences ( $\mathrm{p}=0.001)$.

A significant difference $(p=0.030)$ was also observed when comparing $\mathrm{HBeAg}$ status and ALT. Elevated ALT levels were more frequent in the $\mathrm{HBeAg}$-positive patients $(4 / 8,50 \%)$ compared with the HBeAg-negative patients (6/46, 13\%).

\section{DISCUSSION}

In this study, we characterized HBV subgenotypes in relation to demographic, clinical (HBeAg status/ALT levels) and virological (BCP and precore/core mutations) features in patients chronically infected with HBV from the State of Paraná in Southern Brazil. HBV DNA was amplified using primers that anneal in the conserved regions of the HBV genome, and HBV DNA was detected in $79 \%$ of the 71 samples studied. This detection frequency is in agreement with the sensitivity values reported in the literature ${ }^{50,51}$.
The frequency of genotypes A (26\%) and D (66.7\%) observed here supports the HBV genotyping studies conducted with blood donors from State of Paraná and studies focused on HBV genotype distribution in different regions of southern Brazil, which reported that HBV/D is the most frequent genotype followed by genotype $A^{19,52-54}$. The State of Paraná is one of the states with the widest ethnic variety in Brazil. This state was colonized by people from the Mediterranean region (Spanish, Portuguese and Italians) and from the Middle East (Arabs), which explains the high prevalence of genotype D found in the studied region. Colonization from northwestern Europe (Germans, Poles, Ukrainians, and Dutch), in addition to Africans from the time of slavery, explains the presence of genotype A found in this study. Japanese settlement in Brazil likely brought the characteristic genotypes from their region of origin. Thus, genotype C (5.6\%) was detected in this study as the patients were from the regions in State of Paraná with a large number of immigrants from Asian countries. In this respect, Maringá possesses one of the largest Japanese colonies in the State of Paraná (http://www.parana.pr.gov.br/etnias). According to the literature, genotype $\mathrm{C}$ is characteristically found in Asia. More specifically, subgenotype $\mathrm{C} 2$, the only subgenotype of genotype $\mathrm{C}$ detected in the present study, is commonly found in Far Eastern countries, including Japan, China and Korea ${ }^{55,56}$.

The only patient infected with genotype $\mathrm{E}$ was from GuineaBissau, a country on the western coast of Africa where this genotype is primarily found ${ }^{57}$. The frequencies of genotypes $\mathrm{A}$ and $\mathrm{D}$ found in this study are similar to the frequencies reported by Lindh et al..$^{58}$ for southern Europe where genotype A was detected in $15 \%$ of patients and genotype D in $85 \%$ of patients. Similar findings have been reported for northern Africa where genotype $\mathrm{D}$ is the most prevalent, but the frequency of genotype $\mathrm{A}$ is also significant ${ }^{56}$. Genotype $\mathrm{D}$ as well as its subgenotypes (D1, D2 and D3) is found worldwide but shows a high prevalence in the Mediterranean region, including the Middle East ${ }^{12,21}$. In Europe, genotype D is found in the southern countries that border the Mediterranean Sea and accounts for nearly $100 \%$ of the HBV cases found in Greece, Italy, Serbia and Albania ${ }^{59}$. Based on European published data, HBV/D3 is most prevalent in Italy with a frequency of $40.4 \%$ ( $72.7 \%$ of $\mathrm{HBV} / \mathrm{D})^{60}$. Two subgenotypes of genotype A were identified in the present study: A2, which is prevalent in Europe, and A1, which is prevalent in Africa and Asia ${ }^{61}$. Thus, the presence of genotypes A, C and D and their respective subgenotypes A1, A2, C2, D1, D2 and D3 in the investigated population reflects the immigration that has been occurring in the studied region. State of Paraná specifically received large numbers of Italian and German immigrants, and most of its population is descended from people from these nations ${ }^{62}$. Analysis of the patients as a whole showed no significant difference in clinical characteristics between the three main genotypes ${ }^{1,63}$.

Comparison of the HBV virological characteristics between genotypes $\mathrm{A}, \mathrm{C}$ and $\mathrm{D}$ revealed significant differences in terms of the G1896A and G1862T mutations and the presence of a thymine at position 1858 . A higher $(77.7 \%)$ frequency of the G1896A stop codon mutation was observed in genotype D, and this mutation showed significant association with $\mathrm{HBeAg}$ 
status as all G1896A mutants were HBeAg negative. Genotype $\mathrm{D}$ was the most frequent genotype (69.5\% - 32/46) in HBeAgnegative patients; therefore, a significant difference in the frequency of the G1896A mutation was observed between $\mathrm{HBeAg}$-negative and -positive samples belonging to genotype D. This finding suggests that this mutation is one of the most important factors for early seroconversion of $\mathrm{HBeAg}$. These findings are in agreement with Elkady et al. ${ }^{64}$ who studied mutations in patients infected with genotype D. All genotype $\mathrm{D}$ and $\mathrm{C}$ sequences, including $\mathrm{HBe} A g$-negative and -positive samples, had a thymine $(\mathrm{T})$ at position 1858 , which confers stability to the stem-loop structure of the encapsidation signal in the presence of the G1896A mutation due to base pairing between these positions ${ }^{35,65}$.

In contrast to genotypes $\mathrm{C}$ and $\mathrm{D}$, genotype $\mathrm{A}$ sequences did not harbor the G1896A mutation, which is likely due to the presence of a cytosine (C) at position 1858 in $78.6 \%$ of the sequences. The G1896A mutation is unfavorable in this case as base pairing in the precore pregenomic ribonucleic acid (RNA) is essential for the maintenance of viral replication ${ }^{24,61,66,67}$. Similar results regarding the nucleotide present at position 1858 in each genotype have been reported by Chandra et al. ${ }^{67}$, who observed the presence of a cytosine at this position in $88 \%$ of genotype A samples and the presence of a thymine in $96 \%$ of genotype C and $100 \%$ of genotype D samples. The presence of a $\mathrm{C}$ at position 1858 is primarily found in genotype $\mathrm{A}$ and is frequent in subgenotype $\mathrm{C} 1$ but not $\mathrm{C} 2^{10,68}$.

Analysis of the HBeAg status and serum ALT levels showed a significant difference, with the frequency of elevated ALT levels being higher among HBeAg-positive patients $(50 \%)$ and lower (13\%) among HBeAg-negative patients. In addition, similar results have been reported by Kidd-Ljunggren et al. ${ }^{50}$. When the patients were analyzed for signs of viral replication, the authors observed that HBeAg-positive patients were more likely than anti-HBe-positive patients to have elevated ALT levels (55\% and 24\%, respectively). This result is an interesting finding in the context of immunotolerance, which is believed to exist during the HBeAg-positive phase because elevated ALT levels suggest an immunoreactive state rather than a state of tolerance by the immune system ${ }^{50}$.

In the present study, a significant difference in the distribution of the G1862T mutation was observed between genotypes. Patients infected with subgenotype A1 had the highest frequency $(82 \%$ - 9/11) followed by the patients infected with genotype $\mathrm{D}(18 \%-2 / 11)$. None of the samples belonging to subgenotype A2 or genotype $\mathrm{C}$ harbored this mutation. Similar results have been reported by Chandra et al. ${ }^{67}$ and Tanaka et al. ${ }^{69}$. According to the latter authors, the subgenotypes of genotype A are known to influence the prevalence of G1862T. In contrast, Chandra et al ${ }^{67}$ reported that the G1862T mutation is rare in subgenotype A2 but is common in A1. In addition, these authors did not detect the G1862T mutation in genotype $\mathrm{C}$, which was also observed in the present study. Guarnieri et al. ${ }^{30}$ proposed that the G1862T mutation contributes to the reduced replication capacity of genotype A and that the G1899A mutation relieves the inhibitory effect of G1862T on genome replication by restoring core protein expression. However, no significant difference in the frequency of the G1899A mutation between genotypes was observed in the present study with the observation of an intermediate frequency in genotypes $\mathrm{C}$ and $\mathrm{D}$ and a low (7.1\%) frequency in genotype A.

No significant difference in the frequency of the A1762T/ G1764A BCP mutation was observed between genotypes in this study. However, statistical analysis revealed a result close to significance, which has been reported in other studies ${ }^{25,50}$. The frequency of this double mutation in the BCP gene was higher in genotypes $\mathrm{C}$ and $\mathrm{A}(66.7 \%$ and $64.3 \%$, respectively). The lowest frequency was observed among patients infected with genotype D (30.5\%), which is in agreement with other investigators ${ }^{64,67,69}$. The result may have been significant if a larger sample size was achieved. The frequency of the T1753V mutation, which is also located in the $\mathrm{BCP}$ region, did not differ significantly between genotypes with the observation of an intermediate and similar frequency. These two mutations in the $\mathrm{BCP}$ gene have been reported as risk factors for the development of HCC, and our results show that the virus is primarily mutant at both positions s $^{1,35,36,63,64}$.

The present study found that $14.8 \%$ of patients were $\mathrm{HBeAg}$ positive and identified HBV genotypes $\mathrm{A}, \mathrm{C}, \mathrm{D}$ and $\mathrm{E}$ and subgenotypes A1, A2, D1, D2, D3 and C2 in chronic carriers circulating in the southern region of Brazil. No differences in the clinical characteristics of infected patients were observed between genotypes. However, a significant difference was observed when comparing $\mathrm{HBeAg}$ status and the presence of the G1896A stop codon mutation in patients infected with genotype D (D1, D2 and D3). Most patients carrying this mutation were anti-HBe positive, which demonstrates the existence of a relationship between the HBV G1896A precore mutant and genotype D in $\mathrm{HBeAg}$ seroconversion. Analysis of the mutations showed a well-defined distribution according to genotype. Specifically, a higher prevalence of the G1896A mutation and the presence of a thymine at position 1858 were observed in genotype D samples, whereas genotype A was associated with a higher prevalence of the G1862T and a C at position 1858. Although the difference in the distribution of the A1762T/G1764A mutation between genotypes was not significant, the mutation was more prevalent in genotypes A and $\mathrm{C}$ than genotype $\mathrm{D}$. A correlation between HBV genotypes and mutations in the $\mathrm{BCP}$ and precore/core region was shown, demonstrating that these analyses combined with the detection of $\mathrm{HBeAg}$-positive patients are important tools and essential for the prognosis and treatment of patients with chronic HBV because they are associated with increased risk for the development of HCC. Studies focused on clinical and virological monitoring of larger numbers of patients with chronic HBV are needed to gain a better understanding of HBV disease.

\section{ACKNOWLEDGMENTS}

We thank the Consórcio Intermunicipal de Saúde do Setentrião Paranaense, Clínica Gastrocentro of Maringá and Prof. Rosangela Getirana Santana PhD, Department of de Statistic, State University of Maringá. 


\section{CONFLICT OF INTEREST}

The authors declare that there is no conflict of interest.

\section{FINANCIAL SUPPORT}

This study was supported by the Fundação Araucária of the Department of Science and Technology State of Paraná. The study sponsors had no involvement in the present study.

\section{REFERENCES}

1. Wang Z, Tanaka Y, Huang Y, Kurbanov F, Chen J, Zeng G, et al. Clinical and virological characteristics of hepatitis $\mathrm{B}$ virus subgenotypes $\mathrm{Ba}, \mathrm{C} 1$, and $\mathrm{C} 2$ in China. J Clin Microbiol 2007; 45:1491-1496.

2. Lin CL, Liao LY, Wang CS, Chen PJ, Lai MY, Chen DS, et al. Basal core-promoter mutant of hepatitis B virus and progression of liver disease in hepatitis B e antigen-negative chronic hepatitis B. Liver Int 2005; 25:564-570.

3. Tanaka J. Hepatitis B epidemiology in Latin America.Vaccine 2000; 18 (supl I):17-19.

4. Fernandes JV, Braz RF, Neto FV, Silva MA, Costa NF, Ferreira AM. Prevalence of serologic markers of hepatitis B virus in hospital personnel. Rev Saude Publica 1999; 33:122-128.

5. Kao JH, Chen DS. Recent research progress in hepatocellular carcinoma. J Formos Med Assoc 2002; 101:239-248.

6. Norder H, Hammas B, Lofdahl S, Courouce AM, Magnius LO. Comparison of the amino acid sequences of nine different serotypes of hepatitis B surface antigen and genomic classification of the corresponding hepatitis B virus strains. J Gen Virol 1992; 73:12011208.

7. Okamoto H, Tsuda F, Sakugawa H, Sastrosoewignjo RI, Imai M, Miyakawa Y, et al. Typing hepatitis B virus by homology in nucleotide sequence: comparison of surface antigen subtypes. J Gen Virol 1988; 69:2575-2583.

8. Stuyver L, De Gendt S, Van Geyt C, Zoulim F, Fried M, Schinazi RF, et al. A new genotype of hepatitis B virus: complete genome and phylogenetic relatedness. J Gen Virol 2000; 81:67-74.

9. Orito E, Ichida T, Sakugawa H, Sata M, Horiike N, Hino K, et al. Geographic distribution of hepatitis B virus (HBV) genotype in patients with chronic HBV infection in Japan. Hepatology 2001; 34:590-594.

10. Lindh M, Andersson AS, Gusdal A. Genotypes, nt 1858 variants, and geographic origin of hepatitis B virus--large-scale analysis using a new genotyping method. J Infect Dis 1997; 175:1285-1293.

11. Westland C, Delaney W, Yang H, Chen SS, Marcellin P, Hadziyannis S, et al. Hepatitis B virus genotypes and virologic response in 694 patients in phase III studies of adefovir dipivoxill. Gastroenterology 2003; 125:107-116.

12. Cooksley WG. Do we need to determine viral genotype in treating chronic hepatitis B? J Viral Hepat 2010; 17:601-610.

13. Norder H, Courouce AM, Magnius LO. Complete genomes, phylogenetic relatedness, and structural proteins of six strains of the hepatitis B virus, four of which represent two new genotypes. Virology 1994; 198:489-503.

14. Odemuyiwa SO, Mulders MN, Oyedele OI, Ola SO, Odaibo GN, Olaleye DO, et al. Phylogenetic analysis of new hepatitis B virus isolates from Nigeria supports endemicity of genotype E in West Africa. J Med Virol 2001; 65:463-469.

15. Vieth S, Manegold C, Drosten C, Nippraschk T, Gunther S. Sequence and phylogenetic analysis of hepatitis B virus genotype $\mathrm{G}$ isolated in Germany. Virus Genes 2002; 24:153-156.

16. Yu H, Yuan Q, Ge SX, Wang HY, Zhang YL, Chen QR, et al. Molecular and phylogenetic analyses suggest an additional hepatitis B virus genotype "I". PLoS One 2010; 5:e9297.

17. Olinger CM, Weber B, Otegbayo JA, Ammerlaan W, van der Taelem-Brule N, Muller CP. Hepatitis B virus genotype E surface antigen detection with different immunoassays and diagnostic impact of mutations in the preS/S gene. Med Microbiol Immunol 2007; 196:247-252.

18. Tatematsu K, Tanaka Y, Kurbanov F, Sugauchi F, Mano S, Maeshiro $\mathrm{T}$, et al. A genetic variant of hepatitis B virus divergent from known human and ape genotypes isolated from a Japanese patient and provisionally assigned to new genotype J. J Virol 2009; 83:1053810547.

19. Mello FC, Souto FJ, Nabuco LC, Villela-Nogueira CA, Coelho HS, Franz HC, et al. Hepatitis B virus genotypes circulating in Brazil: molecular characterization of genotype $\mathrm{F}$ isolates. BMC Microbiol 2007; 7:103.

20. Sitnik R, Pinho JR, Bertolini DA, Bernardini AP, Da Silva LC, Carrilho FJ. Hepatitis B virus genotypes and precore and core mutants in Brazilian patients. J Clin Microbiol 2004; 42:2455-2460.

21. Schaefer S. Hepatitis B virus taxonomy and hepatitis B virus genotypes. World J Gastroenterol 2007; 13:14-21.

22. Shinkai N, Tanaka Y, Ito K, Mukaide M, Hasegawa I, Asahina Y, et al. Influence of hepatitis $\mathrm{B}$ virus $\mathrm{X}$ and core promoter mutations on hepatocellular carcinoma among patients infected with subgenotype C2. J Clin Microbiol 2007; 45:3191-3197.

23. Lok AS, Akarca U, Greene S. Mutations in the pre-core region of hepatitis B virus serve to enhance the stability of the secondary structure of the pre-genome encapsidation signal. Proc Natl Acad Sci USA 1994; 91:4077-4081.

24. Kreutz C. Molecular, immunological and clinical properties of mutated hepatitis B viruses. J Cell Mol Med 2002; 6:113-143.

25. Lim CK, Tan JT, Khoo JB, Ravichandran A, Low HM, Chan YC, et al. Correlations of $\mathrm{HBV}$ genotypes, mutations affecting $\mathrm{HBeAg}$ expression and $\mathrm{HBeAg}$ /anti-HBe status in HBV carriers. Int J Med Sci 2006; 3:14-20.

26. Buckwold VE, Xu Z, Chen M, Yen TS, Ou JH. Effects of a naturally occurring mutation in the hepatitis B virus basal core promoter on precore gene expression and viral replication. J Virol 1996; 70:5845-5851.

27. Gunther S, Piwon N, Will H. Wild-type levels of pregenomic RNA and replication but reduced pre-C RNA and e-antigen synthesis of hepatitis B virus with $\mathrm{C}(1653) \rightarrow \mathrm{T}, \mathrm{A}(1762) \rightarrow \mathrm{T}$ and $\mathrm{G}(1764) \rightarrow \mathrm{A}$ mutations in the core promoter. J Gen Virol 1998; 79:375-380.

28. Kramvis A, Bukofzer S, Kew MC, Song E. Nucleic acid sequence analysis of the precore region of hepatitis B virus from sera of southern African black adult carriers of the virus. Hepatology 1997; 25:235-240.

29. Fallows DA, Goff SP. Mutations in the epsilon sequences of human hepatitis B virus affect both RNA encapsidation and reverse transcription. J Virol 1995; 69:3067-3073.

30. Guarnieri M, Kim KH, Bang G, Li J, Zhou Y, Tang X, et al. Point mutations upstream of hepatitis B virus core gene affect DNA replication at the step of core protein expression. J Virol 2006; 80: 587-595.

31. Hou J, Lin Y, Waters J, Wang Z, Min J, Liao H, et al. Detection and significance of a G1862T variant of hepatitis B virus in Chinese patients with fulminant hepatitis. J Gen Virol 2002; 83:2291-2298. 
32. Kao JH, Chen PJ, Lai MY, Chen DS. Basal core promoter mutations of hepatitis B virus increase the risk of hepatocellular carcinoma in hepatitis B carriers. Gastroenterol 2003; 124:327-334.

33. Liu WC, Phiet PH, Chiang TY, Sun KT, Hung KH, Young KC, et al. Five subgenotypes of hepatitis $\mathrm{B}$ virus genotype $\mathrm{B}$ with distinct geographic and virological characteristics. Virus Res 2007; 129:212-223.

34. Takahashi K, Aoyama K, Ohno N, Iwata K, Akahane Y, Baba K, et al. The precore/core promoter mutant (T1762A1764) of hepatitis B virus: clinical significance and an easy method for detection. $\mathrm{J}$ Gen Virol 1995; 76:3159-3164.

35. Tanaka Y, Mukaide M, Orito E, Yuen MF, Ito K, Kurbanov F, et al. Specific mutations in enhancer II/core promoter of hepatitis B virus subgenotypes $\mathrm{C} 1 / \mathrm{C} 2$ increase the risk of hepatocellular carcinoma. J Hepatol 2006; 45:646-653.

36. Yuen MF, Tanaka Y, Fong DY, Fung J, Wong DK, Yuen JC, et al. Independent risk factors and predictive score for the development of hepatocellular carcinoma in chronic hepatitis B. J Hepatol 2009; 50:80-88.

37. Gomaa AI, Khan SA, Toledano MB, Waked I, Taylor-Robinson SD. Hepatocellular carcinoma: epidemiology, risk factors and pathogenesis. World J Gastroenterol 2008; 14:4300-4308.

38. Yang HI, Lu SN, Liaw YF, You SL, Sun CA, Wang LY, et al. Hepatitis B e antigen and the risk of hepatocellular carcinoma. N Engl J Med 2002; 347:168-174.

39. Yuen MF, Yuan HJ, Wong DK, Yuen JC, Wong WM, Chan AO, et al. Prognostic determinants for chronic hepatitis B in Asians: therapeutic implications. Gut 2005; 54:1610-1614.

40. Chomczynski P, Sacchi N. Single-step method of RNA isolation by acid guanidinium thiocyanate-phenol-chloroform extraction. Anal Biochem1987; 162:156-159.

41. Kaneko S, Feinstone SM, Miller RH. Rapid and sensitive method for the detection of serum hepatitis B virus DNA using the polymerase chain reaction technique.J Clin Microbiol 1989; 27:1930-1933.

42. Gomes-Gouvea MS, Soares MC, Bensabath G, Carvalho-Mello IM, Brito EM, Souza OS, et al. Hepatitis B virus and hepatitis delta virus genotypes in outbreaks of fulminant hepatitis (Labrea black fever) in the western Brazilian Amazon region. J Gen Virol 2009; 90:2638-2643.

43. Sanger F, Nicklen S, Coulson AR. DNA sequencing with chainterminating inhibitors.Proc Natl Acad Sci USA 1977; 74:5463-5467.

44. Da Silva LC, Pinho JR, Sitnik R, Da Fonseca LE, Carrilho FJ. Efficacy and tolerability of long-term therapy using high lamivudine doses for the treatment of chronic hepatitis B. J Gastroenterol 2001; $36: 476-485$

45. Hall T. BioEdit: a user-friendly biological sequence alignment editor and analysis program for Windows 95/98/NT. 1999.

46. Thompson JD, Gibson TJ, Plewniak F, Jeanmougin F, Higgins DG. The CLUSTAL $X$ windows interface: flexible strategies for multiple sequence alignment aided by quality analysis tools. Nucleic Acids Res 1997; 25:4876-4882.

47. Tamura K, Dudley J, Nei M, Kumar S. MEGA4: Molecular Evolutionary Genetics Analysis (MEGA) software version 4.0. Mol Biol Evol 2007; 24:1596-1599.

48. StatSoft. STATISTICA® (data analysis software system). $8^{\text {th }}$ ed. StatSoft; 2008.

49. SAS II. SAS OnlineDoc ${ }^{\circledR}$ 9.1.3. Cary, NC: SAS Institute Inc; 2004.

50. Kidd-Ljunggren K, Myhre E, Blackberg J. Clinical and serological variation between patients infected with different Hepatitis B virus genotypes. J Clin Microbiol 2004; 42:5837-5841.

51. Swenson PD, Van Geyt C, Alexander ER, Hagan H, Freitag-Koontz $\mathrm{JM}$, Wilson S, et al. Hepatitis B virus genotypes and HBsAg subtypes in refugees and injection drug users in the United States determined by LiPA and monoclonal EIA.J Med Virol 2001; 64:305-311.
52. Bertolini DA, Ribeiro PC, Lemos MF, Saraceni CP, Pinho JR. Characterization of a Hepatitis B virus strain in southwestern Parana, Brazil, presenting mutations previously associated with anti-HBs Resistance. Rev Inst Med Trop Sao Paulo 2010; 52:25-30.

53. Carrilho FJ, Moraes CR, Pinho JR, Mello IM, Bertolini DA, Lemos MF, et al. Hepatitis B virus infection in Haemodialysis Centres from Santa Catarina State, Southern Brazil. Predictive risk factors for infection and molecular epidemiology. BMC Public Health 2004; 4:13.

54. Becker CE, Mattos AA, Bogo MR, Branco F, Sitnik R, Kretzmann NA. Genotyping of hepatitis B virus in a cohort of patients evaluated in a hospital of Porto Alegre, South of Brazil. Arq Gastroenterol 2010; 47:13-17.

55. Huy TT, Ushijima H, Quang VX, Win KM, Luengrojanakul P, Kikuchi K, et al. Genotype C of hepatitis B virus can be classified into at least two subgroups. J Gen Virol 2004; 85:283-292.

56. Norder H, Hammas B, Lee SD, Bile K, Courouce AM, Mushahwar IK, et al. Genetic relatedness of hepatitis B viral strains of diverse geographical origin and natural variations in the primary structure of the surface antigen. J Gen Virol 1993; 74:1341-1348.

57. Kramvis A, Kew MC. Epidemiology of hepatitis B virus in Africa, its genotypes and clinical associations of genotypes. Hepatol Res 2007; 37:S9-S19.

58. Lindh M, Horal P, Dhillon AP, Norkrans G. Hepatitis B virus DNA levels, precore mutations, genotypes and histological activity in chronic hepatitis B. J Viral Hepat 2000; 7:258-267.

59. Schaefer S. Hepatitis B virus genotypes in Europe. Hepatology Research 2007; 37:S20-S26.

60. Maddalena C, Giambelli C, Tanzi E, Colzani D, Schiavini M, Milazzo L, et al. High level of genetic heterogeneity in S and $\mathrm{P}$ genes of genotype D hepatitis B virus. Virology 2007; 365:113-124.

61. Sugauchi F, Kumada H, Acharya SA, Shrestha SM, Gamutan MT, Khan M, et al. Epidemiological and sequence differences between two subtypes (Ae and Aa) of hepatitis B virus genotype A. J Gen Virol 2004; 85:811-820.

62. Lazier HG. Análise Histórica da Posse de Terra no Sudoeste Paranaense. Fancisco Beltrão, Paraná: Grafit Gráfica e Editora Ltda; 1997.

63. Yuan J, Zhou B, Tanaka Y, Kurbanov F, Orito E, Gong Z, et al. Hepatitis B virus (HBV) genotypes/subgenotypes in China: mutations in core promoter and precore/core and their clinical implications.J Clin Virol 2007; 39:87-93.

64. Elkady A, Tanaka Y, Kurbanov F, Oynsuren T, Mizokami M. Virological and clinical implication of core promoter C1752/ V1753 and T1764/G1766 mutations in hepatitis B virus genotype D infection in Mongolia. J Gastroenterol Hepatol 2008; 23:474-481.

65. Chan HL, Tse CH, Ng EY, Leung KS, Lee KH, Tsui SK, et al. Phylogenetic, virological, and clinical characteristics of genotype $\mathrm{C}$ hepatitis B virus with TCC at codon 15 of the precore region. J Clin Microbiol 2006; 44:681-687.

66. Schaefer S. Hepatitis B virus: significance of genotypes. J Viral Hepat 2005; 12:111-124.

67. Chandra PK, Banerjee A, Datta S, Chakravarty R. G1862T mutation among hepatitis B virus-infected individuals: association with viral genotypes and disease outcome in Kolkata, Eastern India. Intervirology 2007; 50:173-180.

68. Hayashi K, Katano Y, Takeda Y, Honda T, Ishigami M, Itoh A, et al. Association of hepatitis B virus subgenotypes and basal core promoter/precore region variants with the clinical features of patients with acute hepatitis. J Gastroenterol 2008; 43:558-564.

69. Tanaka Y, Hasegawa I, Kato T, Orito E, Hirashima N, Acharya SK, et al. A case-control study for differences among hepatitis B virus infections of genotypes A (subtypes Aa and Ae) and D. Hepatology 2004; 40:747-755. 